\author{
Marek Bernacki \\ Akademia Techniczno-Humanistyczna w Bielsku-Białej \\ mbernacki@ath.bielsko.pl
}

\title{
Śmierć i miłość w poezji Zofii Zarębianki
}

\author{
(Z. Zarębianka, Wiersze dośmiertne, Stowarzyszenie Pisarzy Polskich, \\ Kraków 2017, ss. 71)
}

\section{Death and Love in the Poetry of Zofia Zarębianka}

W najnowszym tomie wierszy Zofii Zarębianki Wiersze dośmiertne $e^{1}$ już sam tytuł daje do myślenia, prowokując czytelnika do wielorakich interpretacji. Słowo „dośmiertne”, będące intrygującym neologizmem, wyrażać może dwie sprawy. Po pierwsze, wskazuje na adresata wierszy, którym jest upersonifikowana Śmierć. Poetka tworzy w perspektywie „do-śmiertnej”, włączając, w sposób barokowo przewrotny swoją przeciwniczkę w krąg tego, co jeszcze żywe, nieumarłe, twórcze. Zaprasza ją do rozmowy, do tańca, prowokuje i kłóci się z nią... Po drugie, analizowane słowo oznaczać może, że wszystko, o czym pisze autorka, wydarza się w heideggerowskim horyzoncie „ku-śmiertnym” $(\text { Sein-zum-Tode) })^{2}$ Z takiej perspektywy oglądu wierszy Zofii Zarębianki każde wypowiedziane poetyckie słowo jest „śmiertelnie” poważne, gdyż ma swoje konsekwencje nie tylko egzystencjalne, ale także eschatologiczne. Podstawowym i najważniejszym punktem odniesienia wypowiedzi podmiotu lirycznego staje się fakt ludzkiej śmierci; końca, który wieńczy dzieło i - być może, choć nie jest to ani pewne, ani oczywiste dla podmiotu tych wierszy - otwiera nową przestrzeń życia „po-śmiertnego”... Warto przywołać w tym miejscu obrazowy sposób myślenia poetki z wiersza bez tytułu:

1 Z. Zarębianka, Wiersze dośmiertne, posł. W. Ligęza, Kraków 2017, ss. 71. (Wszystkie zamieszczone w niniejszym artykule cytaty wierszy pochodzą z tego właśnie tomu - przyp. M.B.).

2 Zauważa to również Wojciech Ligęza, autor posłowia w omawianym tomie: „Poetka układa cykl "wierszy dośmiertnych«, jak rozumiem ten neologizm, wychylonych ku granicznemu doświadczeniu, jasno rozumiejących byt dla- i ku śmierci, uwikłanych w czas płynący, który niesie zagrożenie, złożonych z przeczuć i wizji niepojętych przestrzeni - nie z tego świata, skrajnie więc obcych” (zob. W. Ligęza, Po tąkach wiekuistych galopują konie [w:] Z. Zarębianka, Wiersze dośmiertne, dz. cyt., s. 65). 


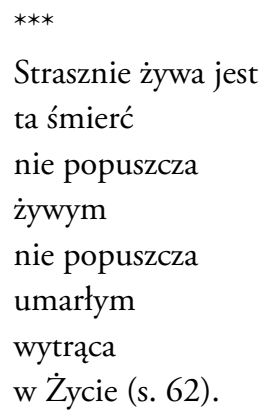

Analizę utworów zawartych $\mathrm{w}$ tomie Wiersze dośmiertne zacznijmy od prześledzenia rozmaitych przejawów motywu tanatologicznego, tworzących literackie kłącze ulepione z różnorodnych konwencji i tropów intertekstualnych. Godny odnotowania jest motyw dotrumienny, czytelnikowi polskiej poezji współczesnej kojarzyć się on może z nihilistyczną twórczością Tadeusza Różewicza, którą przed laty Kazimierz Wyka ochrzcił dosadnie mianem „somatyzmu dotrumiennego"3.

Trudno jednak uznać Zarębiankę, poetkę zanurzoną w tradycji kultury i wiary chrześcijańskiej, za kontynuatorką agnostycznego nurtu Różewiczowskiego z pierwszej, powojennej fazy twórczości autora Niepokoju. Inna rzecz, że dla podmiotu wierszy krakowskiej poetki „sen trumienny ciężki jak wieko" jest co prawda częścią ,„nu o wieczności”, ale zamiast duchowego wyciszenia i pogodzenia się z faktem umierania przynosi somatyczno-psychiczny lęk przed możliwością wiecznej pustki:

Nie uchylę raju powieką

Nie otworzy oczu zdziwienie

Na przecudnie niebieskie przestrzenie

Tylko ciężar i ciemność dokoła

A do nieba nikt jakoś

Nie woła

(*** Nic gorszego niż śmierć się nie zdarzy..., s. 8).

„Dotrumienność” tej poezji realizuje się także w turpistycznym obrazowaniu rodem z poezji Stanisława Grochowiaka, ale mającej zakorzenienie we wcześniejszej stylistyce barokowej, obecnej między innymi w twórczości Mikołaja Sępa-Szarzyńskiego, Daniela Naborowskiego, Jana i Andrzeja Morsztynów czy ks. Józefa Baki ${ }^{4}$. Krakowskiej poetce sen wieczny, sen nieprzespa-

${ }^{3}$ Cyt. za: K. Wyka, Rzecz wyobraźni, https://pl.wikisource.org/wiki/Dyskusja_indeksu: Kazimierz_Wyka_-_Rzecz_wyobra\%C5\%BAni.djvu, dostęp: 19.10.2017.

${ }^{4}$ Zwrócił na to uwagę Bronisław Maj podczas spotkania autorskiego Zofii Zarębianki „Salon literacki SPP w Krakowie", które odbyło się 9 marca 2017 roku w siedzibie Stowarzyszenia Pisarzy Polskich Oddział w Krakowie przy ul. Kanoniczej 7. 
ny jawi się często jako koszmar senny, którego przedmiotem jest zamknięcie w klaustrofobicznej przestrzeni bez wyjścia. W kufrze lub skrzyni, przysypanej ziemią. W śmiertelnej pułapce:

Kwitnie śliwa jak panna młoda

Zgnije w ziemi ręka i noga

Żałobliwa dźwięczy piosenka

dzięcioł stuka rym: do trumienka

Śmiech od śmierci jest niedaleko

mysz pazurek ostrzy o wieko

(Zatosna piosenka, s. 13).

Innym znanym obrazem, który wykorzystuje Zofia Zarębianka w swych zapasach ze Śmiercią, jest motyw danse macabre. Oto jeden z przykładów takiego poetyckiego obrazowania, będący sposobem oswajania śmierci, występujący w omawianym tomie:

Tak zalotnie na nią spogląda

Oko puszcza

Do tańca pociąga

Ciała namiętnie

Pożąda

Śmierć (...)

(*** Tak zalotnie na nia spogląda..., s. 10).

Motyw tańca śmierci powraca w wierszu dedykowanym przyjaciółce Annie Karoń-Ostrowskiej. W tym dynamicznie skonstruowanym utworze, zbudowanym na eksklamacjach tworzących ciąg zdań-krzyków skierowanych w trybie rozkazującym do Niszczycielki: „Uciekaj śmierci ode mnie/ Odejdź sobie daleko/ Schowaj się w jarze za lasem (...) Uciekaj gdzie pieprz rośnie/ Odejdź na koniec świata (...) Nie nagabuj mnie stale/ nie zapraszaj do tańca” - istotną funkcję pełni konceptualna puenta. Końcowy dystych podkreśla bowiem determinację osoby mówiącej, będąc zarazem świadectwem ukrytej rozpaczy podmiotu wiersza: „Uciekaj ode mnie szybko/ Najlepiej umrzyj na zawsze" (Uciekaj, s. 20).

Ważnym elementem analizowanych Wierszy dośmiertnych krakowskiej poetki są te utwory, w których podmiot liryczny, będący wyrazistym porte parole autorki, prowadzi dramatyczny dialog ze Stwórcą. Deus absconditus, milczący Bóg, jest bohaterem kilku wierszy Zarębianki, spośród których na szczególną uwagę zasługują dwa: *** Powinnam za Tobą/ tęsknić... (s. 14) jako przykład, rzec by można, wyrachowanej dysputy z Tym, Który Jest (czy na pewno jest...?), niepozbawionej wszakże szczypty humoru, oraz ${ }^{* * *}$ Wcale 
Ci nie wierzę... (s. 32). Ta druga poetycka rozmowa z Bogiem jest utrzymana w zupełnie innej tonacji. Stanowi zapis doświadczenia granicznego ${ }^{5}$, chwili w której zarówno ciało, jak i dusza człowieka zmierzyć się muszą z próbą kresu życia symbolizowanego przez nieprzenikalną ciemność:

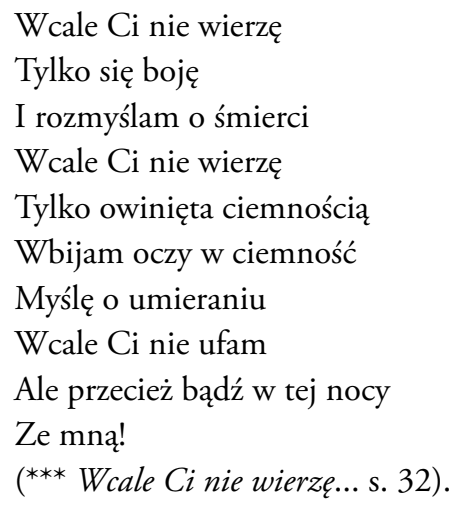

Przytoczony powyżej wiersz jest proweniencji religijnej, autorka nawiązuje w nim do tradycji hiszpańskiego Karmelu i mistycznych wierszy św. Jana od Krzyża czy św. Teresy z Ávila, w których centralnym motywem staje się egzystencjalne doświadczenie „ciemnej nocy duszy”. Notabene uchwycony w słowach zapis ludzkiej trwogi przed śmiercią przypomina ewangeliczną scenę modlitwy Chrystusa w Getsemani. Zmagania Odkupiciela z nadchodzącą śmiercią i prośbę skierowaną do Ojca, aby towarzyszył Mu w chwili przejścia. Słowa: „Ale przecież bądź w tej nocy/ ze mną”, stanowią pogłos Chrystusowej zgody na śmierć ofiarną w obliczu milczącego Boga: „Nie moja, ale Twoja wola niech się spełni”. Są przykładem zawierzenia absolutnego mimo doznawanej przez bohaterkę chwili zwątpienia. Ta gra paradoksami i kontrapunktem to charakterystyczny rys poezji mistycznej, próbującej wyrazić to, czego de facto nie da się wprost słowami wyrazić...

W Wierszach dośmiertnych jest jeszcze jeden krótki utwór, który ukazuje taki właśnie charakter tej poezji. Zbudowany na oksymoronie, oszczędny w słowach i obrazowaniu, łączący skrajnie przeciwstawne emocje, wyraża najgłębsze treści duchowe w sposób, którego nie powstydziliby się ani Rainer Maria Rilke, ani Paul Celan czy poeta milczenia Ryszard Krynicki:

Żarliwy brak

który

płonie w sercu

on jest

${ }^{5}$ Podczas spotkania w Krakowie zwracał na to uwagę Stanisław Stabro. 
znakiem

obecności

(*** Żarliwy brak..., s. 40).

Uzupełnieniem palety literackich i kulturowych motywów mortalnych obecnych w tomie Zofii Zarębianki jest liczna grupa wierszy elegijnych dedykowanych osobom bliskim poetce, które przekroczyły już granicę życia i śmierci. Wśród tych żałobnych tekstów włączonych do najnowszego tomu autorki Czytania sacrum na plan pierwszy wysuwa się cykl zatytułowany Ptacze poJackowe, dedykowany zmarłemu przyjacielowi ks. Jackowi Bolewskiemu - jezuicie, teologowi i myślicielowi religijnemu. W dziewięciu intymistycznych minitrenach poetka nie tylko opłakuje i wspomina swego zmarłego przedwcześnie przyjaciela, ale także czyni coś więcej - sakralizuje jego śmierć, przyrównując ją do męki krzyżowej Jezusa (*** To ciato kruche i/ Ranliwe..., s. 58).

Jak wynika z przedstawionych przykładów, w omawianym tomie zmagania podmiotu lirycznego ze skandalem śmierci ukazane zostały na rozmaite sposoby. Poetka, prowadząc własne zapasy z Niszczycielką, jednocześnie sięga po język intymnego wyznania oraz odwołuje się do topiki tanatologiczno-mortalnej wypracowanej przez wcześniejsze pokolenia twórców.

Mimo nachalnej obecności Śmierci to nie do niej jednak należy w poezji Zofii Zarębianki ostatnie słowo. Siłą, która równoważy moc destrukcji, jest miłość. Bohaterka analizowanego tomu poezji - kobieta wrażliwa, zraniona, walcząca o fizyczne przetrwanie, obnażona w bólu cielesnym i duchowej niemocy, chwilami popadająca w zwątpienie - nie zapomina wszakże o kojącej sile miłości. Dzięki temu wymowa poetyckiego przesłania zyskuje nowy wymiar. Nie jest już wyłącznie skargą, przedśmiertnym żalem czy żałobnym trenem. Poezja Zarębianki otwiera się wyraźnie na przestrzeń łaski obecnej w wymiarze zmysłowo-cielesnym ludzkiego życia, promuje światoodczucie i obrazowanie „ekologiczne”, nie pomijając także dziecięco naiwnej wiary budowanej na pobożności maryjnej. Przyjrzymy się bliżej trzem rozpoznanym tropom, które poetka postawiła niczym tamę dla żywiołu destrukcji szturmującego wrota życia.

Motyw miłości cielesnej, ukazanej jako przejawy ludzkiego ciepła przeciwstawianego zdradliwym zakusom śmierci, pojawia się w wierszu bez tytułu dedykowanemu mężowi poetki (Dla Stasia):

Przytulam się do Ciebie

Ciało do ciała

Ciepło

Dotyk

Pieszczota 
Przytulam się do Ciebie

Jeszcze (...)

(*** Przytulam się do Ciebie..., s. 11).

Ten piękny wiersz pełni funkcję terapeutyczną, ukazując siłę sakramentalnej miłości oblubieńczej, która ratuje człowieka przed poczuciem pustki i lękiem w obliczu nadchodzącego kresu. W tomie Zofii Zarębianki tonacja prywatna nie jest jednakowoż dominująca. Poetka równoważy ją postawą, która swe początki ma we franciszkanizmie, a w dzisiejszych czasach występuje w różnych nurtach myślenia ekologicznego. Przejawem takiej postawy jest wiele wierszy zamieszczonych $\mathrm{w}$ tomie, których bohaterami są zwierzęta, czyli - jakby powiedział św. Franciszek z Asyżu, nasi bracia mniejsi. W jednym z wierszy o takiej właśnie tematyce autorka konstruuje uniwersalną, metaforyczną sytuację liryczną, która daje się czytać jako przejaw franciszkańskiej miłości do naszych „braci mniejszych”, ale równie dobrze potratować ją można jako intrygujący przykład współczesnej poetyckiej teodycei:

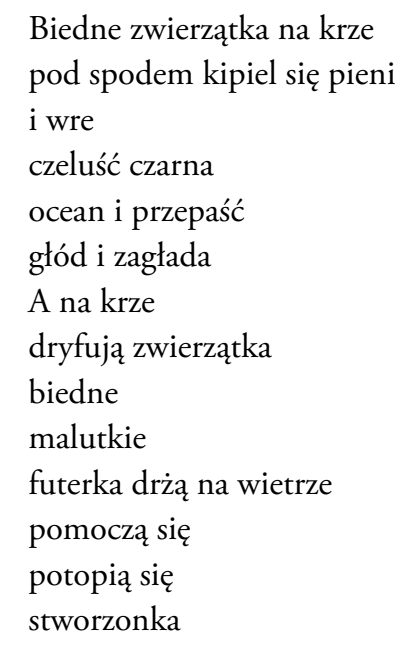

(*** Biedne zwierzątka na krze..., s. 26).

Przytoczony wiersz, jeden z najciekawszych w całym tomie, przywodzi na myśl słynną scenę z Dziennika Witolda Gombrowicza. Pisarz, przechadzając się po plaży nad oceanem, lituje się nad losem bezbronnych owadów:

Żuki jakieś - nie wiem, jak je nazwać - pracowicie snuły się po tej pustyni w celach niewiadomych. I jeden z nich, nie dalej niż na odległość mojej ręki, leżał do góry nogami. Wiatr go przewrócił. Słońce piekło mu brzuch, co zapewne było wyjątkowo nieprzyjemne, zważywszy, że ten brzuch zwykł zawsze pozostawać w cieniu - leżał przebierając łapkami i wiadomo było, że nic innego mu nie pozostaje 
jak tylko monotonne i rozpaczliwe przebieranie łapkami - i już omdlewał, po wielu może godzinach, już konał'

W wierszu Zarębianki malutkie, dryfujące na krze zwierzątka do złudzenia przypominają Gombrowiczowskie żuczki z oceanicznej plaży. W jednym i drugim przypadku te małe stworzenia, którym przyszło mierzyć się w nierównej walce z potężnymi siłami natury, symbolizują kruchość naszego ludzkiego istnienia w zderzeniu z pustą i wrogą, nieludzką siłą kosmiczną, jakimś prażywiołem, który rozpaczliwie próbujemy oswoić za pomocą nauki, religii, sztuki...

Trzeci z wymienionych wcześniej motywów, które w tomie Zarębianki zapisać należy po stronie miłości, a nie śmierci, nazwać można prywatnymi nieszporami maryjnymi odprawianymi za pomocą poezji religijnej. W wierszach dedykowanych Maryi poetka szuka najpierw pociechy w chwili zagubienia, instynktowny lęk przed śmiercią zamieniając w litanijne inkantacje kierowane z modlitewnym zapałem do Matki Bożej (*** Ciemniejąca cieniem/ zielonym..., s. 21). W innym utworze Maryja, ukazana jako „Madonna z Chełmskiej Góry, Madonna ze Skrzatusza i Miriam z Podczela" - urasta, podobnie jak się to dzieje w końcowych partiach części I Fausta Johanna Wolfganga Goethego, do rangi ekumenicznej Zwiastunki pokoju. Jako Ta, Która „Zapala światła/ W menorze/ i tańczy/ Pokój dla świata/ Tańczy/ Potyka się" (*** Madonna z Chetmskiej Góry..., s. 47). Innymi słowy, Maryja z wiersza Zofii Zarębianki staje się ponadczasową egzemplifikacją matczynej twarzy miłosiernego Ojca, który pragnie dla swych dzieci nie śmierci i zagłady, ale wiecznego życia w miłości...

Lektura utworów poetyckich zamieszczonych w najnowszym tomie wierszy Zofii Zarębianki wymaga od czytelnika postawy otwartości wobec fenomenu śmierci, zjawiska, które we współczesnej kulturze jest raczej marginalizowane. W przejmującej, egzystencjalnej poezji, będącej zapisem intymnych zapasów ze śmiercią, autorka śmiało stawia czoło wyzwaniu umierania, które nagle, w samym środku życia, dotknęło właśnie ją. Czyni to w sposób wyważony, obierając za swój oręż poetyckie słowo. Potędze zachłannej Niszczycielki poetka przeciwstawia nawarstwiającą się przez stulecia mądrość i wrażliwość poetyckich konwencji, motywów i obrazów. W nierównej walce ze śmiercią odnajduje też sojusznicze moce, którymi są dla niej: przywiązanie do bliskich osób, franciszkańska miłość wobec wszystkiego, co stworzone, oraz kult Maryi - Matki Miłosierdzia.

\footnotetext{
${ }^{6}$ W. Gombrowicz, Dziennik 1957-1961, Kraków 1989, s. 52.
} 